\title{
SIMPUS eHealth Evaluation at Bantul District Yogyakarta
}

\author{
Lusiana Wiwid Endriani*, Sulistyawati* \\ *Correspondence Author: sulistyawatisuyanto@gmail.com \\ *Faculty of Public Health, Universitas Ahmad Dahlan, Indonesia
}

\begin{tabular}{|c|c|}
\hline I N D E X I N G & A B S T R AC T \\
\hline Keywords: & Indonesia government through the Indonesia Ministry of Health has developing Health Information \\
\hline eHealth; & System, including Primary Health Care Information System Management (SIMPUS), this system \\
\hline IHIS & work as a tool on data acquisition in the society. SIMPUS has been implemented in several districts in \\
\hline SIMPUS; & Indonesia, including Bantul District, Yogyakarta. This research aimed to evaluate SIMPUS eHealth \\
\hline PIECES; & implementation compared to IHIS. Qualitative with case study was used to capture the data in \\
\hline Evaluation; & Piyungan Public Health Centre. A PIECE was employed as an evaluation method. Our respondents \\
\hline & were SIMPUS manager, Medical record officer, Registration officer, and Maternal child \\
\hline & officer. Our research revealed that eHealth was powerful than IHIS. Nevertheless, there were several \\
\hline & limitations on eHealth such as less of control-security and service. For future research suggested \\
\hline
\end{tabular}

Kata kunci:

eHealth;

IHIS

SIMPUS;

PIECES;

Evaluasi;
Pemerintah Indonesia membangun Sistem Informasi Kesehatan termasuk Sistem Informasi Manajemen Puskesmas (SIMPUS) sebagai alat untuk mendapatkan data yang akurat demi meningkatkat derajat kesehatan masyarakat. SIMPUS sudah diimplementasikan di Kabupaten di Indonesia, termasuk Kabupaten Bantul, Yogyakarta. Namun demikian masih terdapat kendala di lapangan dalam implementasi SIMPUS. Penelitian ini bertujuan untuk mengevaluasi implementasi SIMPUS eHealth dibandingkan dengan IHIS. Qualitatif studi dengan pendekatan studi kasus di Puskesmas Piyungan digunakan dalam penelitian ini. Sedangkan metode evaluasi yang digunakan adalah PIECES. Responden dalam penelitian ini terdiri dari empat orang yaitu Pengelola SIMPUS, Petugas SIMPUS bagian KIA, Petugas SIMPUS bagian pendaftaran, dan Petugas SIMPUS di bagian rekam medis. Penelitian ini mengungkapkan bahwa eHealth lebih powerfull dibanding IHIS, namun terdapat kelemahan dari sisi Control-Security dan Service. Penelitian yang akan datang direkomendasikan untuk melibatkan sampel Puskesmas yang lebih banyak dalam rangka menangkap permasalahan secara komprehensif.

(C) 2019 JMMR. All rights reserved

\section{INTRODUCTION}

Health Information System (HIS) in particular country influences the health status of that country. It is due to the data from HIS will used as data input on decision making. Good data collection produces accurate and credible information on that purpose. WHO highlights the importance of information available as system building blocks. ${ }^{-}$In Indonesia, health services delivery is involving various part, all of which are the hospital, private clinic and Primary Health Centre (PHC). All those facilities require equipment to control and ensure the information credibility.

Health information system for primary health centre called SIMPUS is an important part of HIS because SIMPUS responsible for primary data collection in the associated PHC. This data will be used for capturing community health status on PHCs area. $\stackrel{2}{-}$ Moreover, SIMPUS as a changing paradigm from manual report to computerise based report aimed for improving the quality of health report.

Indonesia government through The Ministry of Health has attempted to strengthen HIS through the development of SIMPUS. All the time, the government had launched several types of SIMPUS such as IHIS, eHealth, Simpus, $\mathrm{Kartini}^{3}$, with aimed for updating the existing version. For example, IHIS was updated at 2010, purposed to renew the previous IHIS.

eHealth is a health information program that can be applied in all health facility include in PHC. ${ }^{4}$ However, in fact, not all PHC switched to eHealth, even though eHealth is claimed to have higher performance than IHIS. This 
statement is supported by previous research that eHealth was more accessible to use and applicable in PHC. . $^{-}$ Unfortunately, with all benefits, some PHCs remains to choose not to apply this system.

In Bantul, SIMPUS has widely used since 2007, and it played a substantial role to support health care delivery referred to the conformity between human, organisation and technology. One of PHC who implementing SIMPUS is Piyungan PHC..$^{5}$ According to Piyungan health staff information, SIMPUS that are applied was developed by Yogyakarta Provincial Health office in cooperation with a private company. Piyungan PHC was applied to Integrated Health Information Systems (IHIS) since 2007-2016. Afterwards, they moved to Electronic Health (e-Health). This changes by a consideration that eHealth equipped with bridging to BPJS through P-Care BPJS menu. Therefore, twice data entry is not required as if when using IHIS. Accordingly, Piyungan PHC could be a reference to the changing system from IHIS to eHealth.

PIECES (Performance, Information, Economy, Control, Efficiency, Service) is a method for evaluating health information with aimed to identify the potential problem arises in the system implementation. Evaluation aim is to improve the system performance through several aspects: Performance, Information, Economy, Control, Efficiency, and Service. ${ }^{-}$PIECES will guide to find some problem during the system implementation. ${ }^{6,-7}$

This research aimed to evaluate eHealth performance compared to IHIS in Piyungan PHC, Bantul, Yogyakarta. This study elaborates existing SIMPUS with previous SIMPUS to provide evidence on this field.

\section{RESEARCH METHOD}

This study was designed as a qualitative. We collected the information from four respondents consist of SIMPUS manager and three staffs: Medical record officer, Registration officer, Maternal and child officer. Informants were selected purposively by criteria inclusion as follows: had two years' work experience at the PHC and knowledgeable with both IHIS and eHealth. Data validity was measured by triangulation among the respondent and a short survey.

This research was conducted at July-August 2017 in Piyungan, Bantul PHC. Data collection was done in two phases: 1) in-depth interview with the four respondents and 2) a survey by using Likert scale item to 10 respondents, all of them experienced with SIMPUS. That second phase was applied to support the in-depth interview information.
Informed consent was obtained prior to the study. Interviews were recorded with the respondent's permission.

The analysis was performed per phase. Phase 1 was started with transcription verbatim for all the recording. Qualitative descriptive was used to analyse the material. In the second phase, the questioner was entry and tabulated.

This study has received a permit from Bantul District Office and Piyungan Bantul PHC.

\section{RESULT AND DISCUSSION}

\section{Performance}

According to the interview, response time e-Health was faster than IHIS. eHealth system based on bridging P-Care. Respondent reported, in eHealth data entry only requires one step while IHIS have to do in two stages.

“...eHealth system comes with BPJS bridging. eHealth already online so we need only one entry and done. IHIS needs 2 steps or even 3. So, work is faster by using eHealth..." (Medical record officer).

“...e-Health is faster because it directly goes to bridging $P$ Care, while IHIS need 2 steps, and need open 2 application: IHIS and BPJS..." (Maternal and child officer).

Interface for both e-Health and IHIS were reported easy to be understood and need no much time to learn. However, there was one added value of eHealth, this system already adjusted with BPJS system through the presence of a menu for BPJS entry, while IHIS was not.

“...easy. for the first time using eHealth only need 2-3 days to adapt. eHealth interface is easy, only need one "Klik" then data already inputted in BPJS database because of eHealth use bridging system..." (Medical record officer).

“...eHealth interface is easy, with learn 2/3 times will get used to operating this system..." (Registration officer)

“...Easy, eHealth easy to be understood...(SIMPUS manager)

Respondent reported some barriers in eHealth usage: eHealth is online system and rely on internet connection, electricity and risky to virus or Malware attack that potentially disturbs the service to the patient because the 
computer needs to be restarted for several times. And when it happens, the system takes time to load and connect back to the BPJS menu. While IHIS was an offline system, so it worked differently.

“...it depends because e-Health is online. It risks to virus and Malware, and something bad occurs when the electricity was shut..." (SIMPUS manager)

"...the failure of e-Health system is quite a lot however it easy to solve..." (Medical record officer)

Table 1. Evaluation of SIMPUS e-Health: Performance

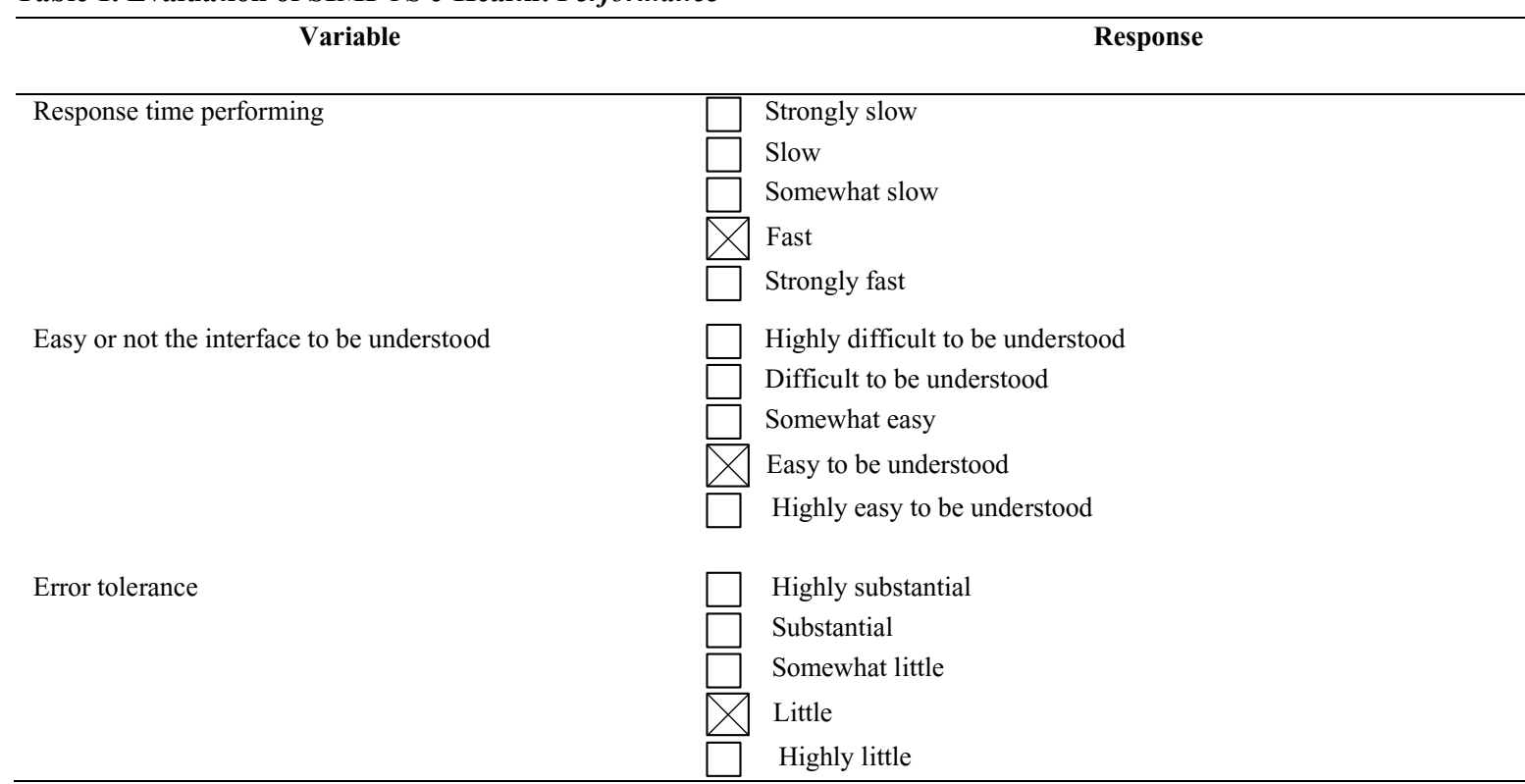

\section{Information and Data}

Informant expressed the data accuracy of eHealth was around $75-85 \%$. SIMPUS manager revealed that still there was data which should be analysed manually. Therefore, accuracy data for eHealth not fully $100 \%$, it depends on the entry process and the sophistication of the system.

“...Accuracy data depend on data entry. Estimated the accuracy was around 75-80\%..." (Registration official).

“...data accuracy about $80-85 \%$ out of $100 \%$. Because eHealth is good and sophisticated..." (Maternal and child officer)

eHealth is more suitable compared to IHIS. Because in eHealth we can see the number patient visit previously. Data search likewise easier performed in eHealth. eHealth is completed with P-Care, by using treasure menu, the
“...e-Health sometimes breaking related to electricity shut." (Registration officer)

"...IHIS is easy to use because it is not an online system. Therefore, then electricity is off, just press power again and system ready to use. It's different with eHealth which based on online system and the problem will come out when the electricity off then needs a quite a long time to connect again..." (SIMPUS manager)

officer only needs the number of the insurance member (BPJS) then if all match, the patient name will be displayed. While in IHIS not equipped yet with this menu.

"Searching process between eHealth in IHIS both are easy. However, eHealth is easier because only need BPJS member register..." (SIMPUS manager)

“...e-Health easier compared to IHIS. IHIS have to search carefully to avoid the wrong name because a lot of patients has a similar name. When using eHealth only need to put the insurance registration, so easy and fast..." (C, maternal and child officer) 


\begin{tabular}{|c|c|}
\hline Variable & Response \\
\hline \multirow[t]{5}{*}{ Accurate } & Highly not accurate \\
\hline & Not Accurate \\
\hline & Somewhat accurate \\
\hline & Accurate \\
\hline & Highly accurate \\
\hline Information & Highly not relevance \\
\hline \multirow[t]{4}{*}{ Relevance } & Not relevance \\
\hline & Somewhat relevance \\
\hline & Relevance \\
\hline & Highly relevance \\
\hline \multirow[t]{5}{*}{ Data flexibility } & Highly difficult \\
\hline & Difficult \\
\hline & Somewhat easy \\
\hline & Easy \\
\hline & Highly easy \\
\hline
\end{tabular}

\section{Economic}

E-Health needs only a few human resources (2-3 people) compared to IHIS that need more people because sometimes IHIS needs manually work. In contrast, for maintenance, eHealth needs more financial supply compared to IHIS because eHealth necessities online support such as software for Virus and Malware protection to avoid the virus attacks the hardware.

“...Human resources only need two people on eHealth while IHIS perhaps need around 4. eHealth is a computerised system, so it is paperless. In Piyungan PHC, people who operate the system is an officer who familiar with the computer, accordingly only need a little resource for eHealth. Indeed, maintenance of eHealth more expensive than IHIS because it risks to virus and Malware. Malware potentially attacks the hardware, and if it happens the cost will be higher compared to IHIS..." (D SIMPUS manager).

Table 3. Evaluation of SIMPUS e-Health: Economic

\begin{tabular}{lll}
\hline \multicolumn{1}{c}{ Variable } & \multicolumn{1}{c}{ Response } \\
\hline Resource & Strongly high cost \\
$\square$ & High cost \\
$\square$ & Somewhat cost \\
$\square$ & Low cost \\
$\square$ & Strongly high cost \\
\hline
\end{tabular}

\section{Control or Security}

All user of PHC health information system both in eHealth and IHIS has a specific role and restricted accordingly. They have a password to enter the system.

“...Access eHealth and IHIS are protected by password...." (SIMPUS manager)

“...security system for eHealth and IHIS are the same, using a password..." (Medical record officer).

However, the password for all paramedic staff was the same - accordingly, eHealth considering less secured compared to IHIS. Thus, related to virus consideration and the same password for all. To anticipate data loss, PHC officer backs up the data routinely every week.

“...For security, IHIS is more secure than eHealth. Because of eHealth risk to Malware and virus. Accordingly, every week our officer is backup the saved data, so when something happens we restore the data, and it can be used again..." (SIMPUS manager)

Table 4. Evaluation of SIMPUS e-Health: Control/Security

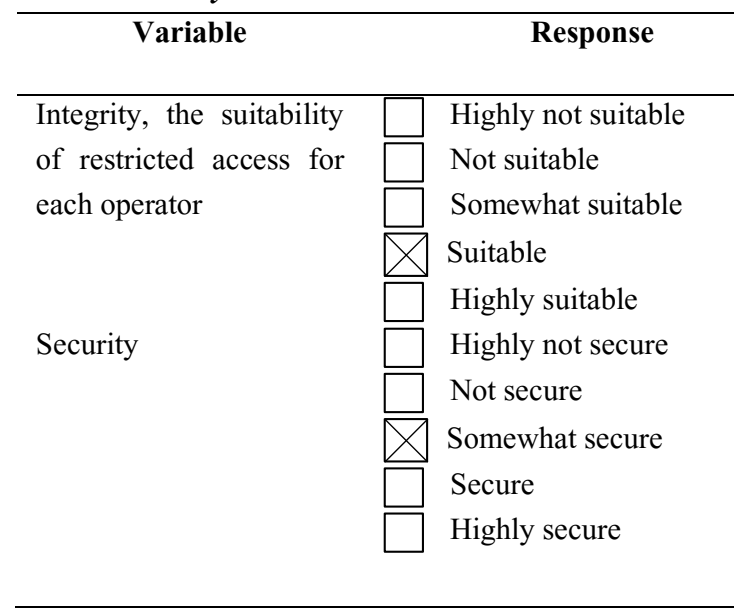

\section{Efficiency}

The informant reported that more efficient operates IHIS than eHealth. eHealth frequently changes the program related to BPJS updating. Those changes require more time to adapt to the new version. In Contrast, IHIS rarely to perform an update. 
“...actually, eHealth not difficult but eHealth still under development. While IHIS is ready to use. eHealth challenge, yes, we found, because BPJS still under developing and it changes many times. For us, follows the changes is not easy..." (SIMPUS manager)

However, the informant said searched and revised for a mistake in eHealth was easier than IHIS, particularly for medical record section who responsible for data collection aimed for medical support. When there was wrong input,
IHIS was difficult to track because it needs manual checking.

"...Found a mistaken entry in eHealth is easier than IHIS, likewise, the modification is easy. IHIS was old version" (SIMPUS manager)

"...looking and refining error input is easy in eHealth because eHealth is a sophisticated system..." (Medical record officer)

Table 5. Evaluation SIMPUS e-Health: Efficiency

\begin{tabular}{|c|c|}
\hline Variable & Response \\
\hline \multirow[t]{5}{*}{ Usability } & Highly challenging \\
\hline & Challenging \\
\hline & Somewhat easy \\
\hline & Easy \\
\hline & Highly easy \\
\hline \multirow[t]{5}{*}{ Maintainability } & Highly challenging \\
\hline & Challenging \\
\hline & Somewhat easy \\
\hline & Easy \\
\hline & Highly easy \\
\hline
\end{tabular}

\section{Service}

eHealth performs high accuracy than IHIS. eHealth system that based on P-Care requires BPJS registration number of the patient before continuing to the service menu. It is different with IHIS that not able to detect mistake when the officer makes an error data entry. Both the eHealth system and IHIS are trusted in helping the PHC services. The two systems are easy to operate. Usage barrier of eHealth rose when PHC have a problem with the internet connection due to eHealth is an online system.

"...e-Health and IHIS are both easy to operate. Before eHealth was implemented, I received training from BPJS on how to use this system. BPJS and the PHC gave special training to me. Accordingly, I have to deliver to other people who will operate eHealth." (SIMPUS manager).

Table 6. Evaluation SIMPUS e-: Service

\begin{tabular}{|c|c|}
\hline Variable & Response \\
\hline \multirow[t]{5}{*}{ Work process accuration } & Highly not detail \\
\hline & Not detail \\
\hline & Somewhat detail \\
\hline & Detail \\
\hline & Highly detail \\
\hline \multirow[t]{5}{*}{ Data reliability } & Highly not reliable \\
\hline & Not reliable \\
\hline & Somewhat reliable \\
\hline & $\bigotimes$ Reliable \\
\hline & Highly reliable \\
\hline
\end{tabular}




\begin{tabular}{lll}
\hline Variable & \multicolumn{1}{c}{ Response } \\
\hline Simplicity & $\square$ Highly complex \\
& Complex \\
\hline & Somewhat complex \\
& Simply \\
& Highly simply \\
\hline & & \\
\hline
\end{tabular}

This study discusses eHealth implementation trough PIECES approach - Performance, Information, Economic, Control, Efficiency and Service. This research revealed overall eHealth is more powerful than IHIS. This finding is supported by the previous study which reported that eHealth quality is better than IHIS..$^{-}$However, from efficiency and control, eHealth user did not satisfy with the system. Performance of a particular system is measured by how fast a system to deliver services aimed to improve the health quality of the society. ${ }^{-}$In this research shown, that eHealth more effective which only requires once input and directly connected to BPJS, while IHIS need twice entry. Bridging BPJS is a system created with aimed at increase data entry effectivity to reduce resources consumption and correspond to BPJS, it would speed up the claims. ${ }^{9}$ Accordingly, eHealth is supporting PHC to produce good service delivery to the patient. This is consistent with research by Lestari who stated that system speed is essential to help a work performance. ${ }^{10,11}$ eHealth deliberates as to simplify the administration work, in context deliver a fast response when performing administration function such as in BPJS. $\stackrel{12}{ }$

eHealth is paperless system; $\frac{13}{}$ therefore it can be operated with a minimum number of human resources. Thus it gives benefit in term of simplifying the coordination among the people involved. However, according to previous research, the gain can be achieved if the intended person can solve problem in those system. ${ }^{11}$ For maintenance, eHealth consumes higher fund resources than IHIS due to the anti-virus routine update.

System accuracy is essential to guarantee the precision of the data analysis. ${ }^{14}$ eHealth provides great data accuracy; it makes patient service performs quickly and satisfying compared to IHIS.

This research may have some limitations: this research was conducted merely in one PHC, so possible there is a different result in other PHC depends on the local situation. It implies to be careful about generating this result.

\section{CONCLUSIONS}

The conclude that eHealth is powerful than IHIS, however still there is potential gaps should be filled in such as the worries of the user to the data security. Secondly, eHealth always attempts refining, so often it is being updated. It is considered as not efficient for the user because they have to provide time and energy to learn a new menu.

\section{ACKNOWLEDGEMENT}

We express our gratitude to all participant and the staff of Piyungan PHC for their support during this research

\section{REFERENCES}

1. Manyazewal T. Using the World Health Organization health system building blocks through survey of healthcare professionals to determine the performance of public healthcare facilities. Arch Public Heal. 2017;75(1):1-8. doi:10.1186/s13690-017-0221-9.

2. SIMKES. Sistem Informasi Puskesmas dalam PerMenKes No. 44 tahun 2016. Web Page SIMKES. http://sisteminformasikesehatan.net/2016/10/26/sisteminformasi-puskesmas-dalam-permenkes-no-44-tahun2016/. Published 2016. Accessed July 6, 2018.

3. Suprawoto T, Sumiyatun. Seleksi Pemilihan Sistem Informasi Manajemen Puskesmas Menggunakan Metode AHP Studi Kasus Dinkes Kabupaten Bantul. In: Seminar Nasional Teknologi Informasi Dan Komunikasi 2013. Vol 2013. Yogyakarta: SENTIKA; 2013.

4. Kementerian Kesehatan Republik Indonesia. EHEALTH Percepat Capai Target MDG's. Web Page Kemenkes.

http://www.depkes.go.id/development/site/jkn/index.ph p?cid=1612\&id=e-health-percepat-capai-targetmdgs.html. Published 2011. Accessed July 8, 2018.

5. Zaenab SN. Pengalaman Aplikasi EHealth Untuk Koordinasi Dan Kolaborasi Antara Puskesmas Dan Dinas Kesehatan. Bantul; 2010. http://kebijakankesehatanindonesia.net/sites/default/file s/Diana Setyawati Rahayu, SKM, MSE.pdf.

6. Tardiyanto S, Saputro E. Jus tekno. JUS TEKNO. 2017;01(01):83-92.

7. Widodo F. Evaluasi penerapan sistem Informasi Manajemen Puskesmas (SIMPUS) di Kabupaten 
Bantul. 2013.

8. Leon N, Brady L, Kwamie A, Daniels K. Routine Health Information System (RHIS) interventions to improve health systems management ( Protocol ). Cochrane Database Syst Rev. 2015;(12). doi:10.1002/14651858.CD012012.

9. Mahmudah PN, S C, Wigati PA. Analisis Upaya Rumah Sakit Islam Sultan Agung Kota Semarang sebagai Fasilitas Kesehatan Tingkat Lanjut dalam Penerapan Program Jaminan Kesehatan nasional Tahun 2014. J Kesehat Masy. 2015;3(1):57-64.

10. Lestari WH, Kurniadi A, Setyowati M. Evaluasi Sistem Informasi Manajemen Rumah Sakit di Rumah Sakit Rajawali Citra Bantul Yogyakarta Tahun 2014. 2014;3. http://eprints.dinus.ac.id/6634/1/jurnal_13399.pdf.

11. Kisdianata W, Pribadi F, Fauziah, Fauziyah. Evaluasi
Kinerja Sistem Informasi Manajemen Dalam Mendukung Proses Manajemen di Rumah Sakit Gigi dan Mulut UMY. J Asos Muhammadiyah Magister Adm Rumah Sakit. 2016;2(2):1-8.

12. Rustiyanto E. Sistem Informasi Manajemen Rumah Sakit Yang Terintegrasi. Edisi Revi. Yogyakarta: Gosyen Publishing; 2011.

13. Puspitasari IM, Soegijoko S. e-Prescription: An eHealth System for Preventing Adverse Drug Events in Community Healthcare. $J$ Farm Klin Indones. 2012;1(1):6-15.

14. Setyaningrum A. Analisis Sistem Informasi Registrasi Pasien dengan Metode PIECES di Rumah Sakit Mulia Hati Wonogiri. 2015. 